\title{
A NON-RANDOMISED CONTROLLED TRIAL STUDY BETWEEN NIFEDIPINE AND ISOXSUPRINE AS TOCOLYTICS FOR PRE-TERM LABOUR
}

\author{
Mrinal Kanti Kundu1, Manas Kumar Saha², Kamalika Das ${ }^{3}$ \\ ${ }_{1}^{1}$ Associate Professor, Department of Obstetrics and Gynaecology, Calcutta National Medical College and Hospital, Kolkata, \\ West Bengal, India. \\ ${ }^{2}$ Assistant Professor, Department of Obstetrics and Gynaecology, Diamond Harbour Government Medical College and Hospital, \\ Diamond Harbour, West Bengal, India. \\ 3Postgraduate Trainee, Department of Obstetrics and Gynaecology, Calcutta National Medical College and Hospital, Kolkata, \\ West Bengal, India.
}

\section{BACKGROUND}

ABSTRACT

Preterm labour and delivery are one of the biggest challenges for obstetricians, as they show increasing trends in the countries where data is available. Preterm labour and delivery remain a major cause of perinatal morbidity and mortality. Preterm delivery affects $11 \%$ in US ${ }^{11]}$ or even greater in developing countries $\left(23.3 \%\right.$ in India) ${ }^{[2]}$ and it accounts for $40-75 \%$ of neonatal deaths. Prediction and prevention of preterm labour is not possible despite extensive research on the subject. So, we have to face preterm labour and manage our patients according to their gestational age. So, our aim in the management of preterm labour is to arrest the labour process at least for $48 \mathrm{hrs}$. to obtain the lung maturity by inj. Betamethasone. By these we can at least reduce the risk of respiratory distress syndrome, but could not exempt the baby from other complications of prematurity. Numerous drugs and interventions have been used to prevent and inhibit preterm labour, but none have been found to be completely effective with the choice being further limited by troublesome side effects. The tocolytic agents which are frequently used in obstetric practice are $\beta$ adrenergic receptor blocking agent like isoxsuprine hydrochloride and calcium channel blocker like nifedipine are two commonly used tocolytic agents in India.

The aim of this observational cross-sectional study is to assess the most effective tocolytic agent between nifedipine and isoxsuprine for prevention of preterm labour.
\end{abstract}

\section{MATERIALS AND METHODS}

This is a non-randomised controlled trial study done in Calcutta National Medical College and Hospital, Kolkata, G and 0 Department. This study was done during the period between January 2016 and December 2017.

\section{RESULTS}

A study was done on 50 cases of Pre-Term Labour (PTL) between 28 - 36 weeks: Group A (25 cases) were treated with oral Nifedipine and Group B (25 cases) were treated with parenteral followed by oral Isoxsuprine. Descriptive statistical methods were used for outcome analysis. Outcomes including gestational age at delivery, prolongation of pregnancy, maternal and foetal side effects were noted and analysed. Majority of patients were in the younger age group around 33 - 35 weeks of gestation. Majority of patients among this age group were primigravidae. In our study, use of nifedipine leads to prolongation of pregnancy around 4 weeks and delivery occurred around 37 weeks with good foetal outcome. In few cases, drugs were withdrawn due to some side effects.

\section{CONCLUSION}

There is a high incidence of preterm labour in India. Nifedipine is a better tocolytic drug than isoxsuprine hydrochloride, especially when started with the earliest signs of preterm labour.

\section{KEY WORDS}

Pre-Term Labour (PTL), Tocolytic Drugs, Betamethasone, Nifedipine, Isoxsuprine Hydrochloride.

HOW TO CITE THIS ARTICLE: Kundu MK, Saha MK, Das K. A non-randomised controlled trial study between nifedipine and isoxsuprine as tocolytics for pre-term labour. J. Evolution Med. Dent. Sci. 2018;7(40):4336-4339, DOI: 10.14260/jemds/2018/967

'Financial or Other Competing Interest': None.

Submission 15-05-2018, Peer Review 15-09-2018,

Acceptance 21-09-2018, Published 01-10-2018.

Corresponding Author:

Dr. Manas Kumar Saha,

Ujjwala Bhawan,

Flat No. 3C/1

Gorekhara,

Ghoshpara, Kolkata-150,

West Bengal, India.

E-mail:drmanas.saha@gmail.com

DOI: $10.14260 /$ jemds $/ 2018 / 967$

\section{BACKGROUND}

Preterm labour and delivery are among the most challenging obstetric complications encountered by the obstetricians.

Incidence of pre-term delivery is $24 \%$ in India and responsible for $45-70 \%$ of neonatal deaths. ${ }^{[1,2]}$ Although, the cause of preterm labour is unknown, obstetricians who provide obstetric care should familiarise themselves and their patients with the predisposing risk factors. The clinical factors associated with preterm labour are low socioeconomic status, maternal age $<18$ or $>40$ yrs., smoking, previous history of preterm delivery, infection and some uterine factors (uterine volume increased, uterine anomaly and trauma). A number of studies have attempted to identify clinical and biochemical markers of preterm labour 
and delivery associated with overall poor predictive values. The most promising of the biochemical markers are the presence of foetal fibronectin in the cervico-vaginal secretions, serum cytokines (IL-6), 17-beta estradiol, progesterone and salivary estriol level. Clinically, there are some risk scoring system (Assessment of cervical length by manual or ultrasound examination, monitoring of uterine activity clinically or by tocodynamometry and vaginal bleeding by pelvic examination), which can predict preterm labour. The rate of foetal morbidity can be reduced with early and accurate diagnosis and interventions of preterm labour. Interventions to delay preterm labour are bed-rest, administration of corticosteroids, use of tocolytic drugs and provision of neonatal care. The aim of the short-term use of tocolytic drugs is to delay the delivery for at least $48 \mathrm{hrs}$. for action of betamethasone to reduce the risk of RDS. Drugs used for tocolysis include nifedipine, isoxsuprine, MgSo4, ritodrine, terbutaline and indomethacin. Recent studies have shown that oxytocin receptor inhibitors (atosiban) may also be effective. The effectiveness of tocolytic drugs are controversial and it has some limitations due to some lifethreating complications. Thus, selection of the patient before using any tocolytic drugs is very important to reduce the foetomaternal complications. At present, we obstetricians are using nifedipine, isoxsuprine and atosiban as tocolytic agents for prevention of preterm labour. As atosiban is costlier and is not easily available in the market, it is not a cost-effective drug for the treatment of preterm labour in the tertiary care centres of the developing countries like India where most of the patients belong to low socio-economic status. So, options are limited to either isoxsuprine or nifedipine with the hope of better foetomaternal outcome.

Nifedipine, a calcium channel blocker, given orally inhibits smooth muscle contraction by impeding the flow of calcium across the muscle cell membrane and is safer and better tolerated.

Isoxsuprine is a beta sympathomimetic drug. When it is given parenterally shows rapid tocolytic effect. Oral administration is used for maintenance therapy. However, they have significant and potentially serious maternal and foetal side effects.

\section{Aims and Objectives}

To describe efficacy of nifedipine and that of isoxsuprine as tocolytics in preterm labour.

\section{MATERIALS AND METHODS}

A non-randomised controlled trial, total 50 number of patients selected for the study from Calcutta National Medical College and Hospital, Kolkata, G and 0 department. This study was done during the period between January 2016 and December 2017.

\section{Inclusion Criteria}

Antenatal women having singleton pregnancy with gestational age between 28 and 36 weeks, having one to two regular uterine contractions occurring in 10 mins each lasting for 30 seconds, cervical effacement of more than $50 \%$, cervical dilatation less than $3 \mathrm{~cm}$ with intact membrane and no previous administration of tocolytics.

\section{Exclusion Criteria}

Multiple pregnancy, polyhydramnios, Premature Rupture of Membrane (PROM), medical disorders in pregnancy, severe IUGR.

\section{Selection of Patients}

It is taken by convenient sample size technique since the duration of the study was 1 year.

\section{Methodology}

\section{Manner of Allocation of the Patients}

Patients admitted in the labour room on Wednesday under Unit I, who fulfils the inclusion criteria starting from first week of January 2016 were included in our study. Out of which all odd no. patients were managed with nifedipine, whereas these with even nos. are given isoxsuprine.

Among the 50 cases of pre-term labour patients admitted in labour room, Department of Gynae and Obst, CNMC and $\mathrm{H}$ were allotted in two groups.

Odd numbers i.e. Group A (Nifedipine) 25 cases and even numbers i.e. Group B (Isoxsuprine) 25 cases.

Patients allotted to Group A were given $20 \mathrm{mg}$ oral Nifedipine initially and $10 \mathrm{mg}$ repeated every 20 minutes for upto 4 doses. Thereafter, oral Nifedipine $10 \mathrm{mg}$ given every 6 hrs. upto 7 days.

Patients allotted to Group B were given injection Isoxsuprine $10 \mathrm{mg}$ intramuscular and repeated at six hourly intervals for $48 \mathrm{hrs}$. Patients responding are switched over to oral Isoxsuprine $10 \mathrm{mg}$ six hourly upto 7 days.

\section{Methods of Analysis}

Chi-square and t-test are used to measure the outcome in this study.

\section{RESULTS}

1. Primigravida were more in Group B (48\%) as compared to Group A (44\%), which was not statistically significant.

2. Majority of the patients were between $33-35$ weeks of gestation (88\% in Group B vs. $76 \%$ in Group A), which is not statistically significant.

3. Prolongation of pregnancy was more in Group A of 24.2 days when compared to Group B i.e. 14.96 days. It is dependent on the gestational age at the onset of tocolytics to delivery. The prolongation of pregnancy is not statistically significant as it is short duration of study and sample size is small where they presented at different gestational age.

4. Period of gestation at the time of delivery $\geq 37$ weeks was $68 \%$ cases in Group A compared to $52 \%$ in Group B, which is statistically significant, which signify Nifedipine is a better choice of tocolytics as compared to Nifedipine to arrest pre-term labour and more chances towards term delivery.

5. Mean birth weight of infants delivered was $2.3 \mathrm{~kg}$ in Group A with Apgar scores of $>9$ at 1 minute at birth and mean birth weight of infants delivered was $2.2 \mathrm{~kg}$ in Group B with Apgar scores of $>7$ at birth, which signify using Nifedipine (Group A) to arrest preterm labour can significantly increase the chances of better foetal outcome.

6. Maternal side effects like hypotension and tachycardia were common in Group B, while facial flushing occurred in few cases of Group A patients. Mild respiratory 
distress syndrome was noted in some infants of Group B patients, while foetal tachycardia was observed occasionally in Group A patients.

7. Nifedipine group (Group A) has more success rate in comparison to Isoxsuprine group (Group B), as more number of term deliveries occurred in case of Nifedipine user as tocolytic drugs with good foetal outcome (measured by APGAR score). Treatment was taken to be successful if there was abolition of uterine contractions, no progression of cervical dilatation and if contraction did not recur within 48 hrs. of cessation of therapy. Treatment was considered failure if despite scheduled treatment mentioned in both groups, uterine relaxation was not achieved, or patient or foetus developed some significant side effects that required discontinuation of therapy.

\begin{tabular}{|c|c|c|c|c|}
\hline & $\begin{array}{c}\text { Tocolytic Drugs } \\
\text { Used }\end{array}$ & N & Mean & $\begin{array}{c}\text { Std. } \\
\text { Deviation }\end{array}$ \\
\hline \multirow{2}{*}{ AGE } & A & 25 & 21.52 & 3.676 \\
\cline { 2 - 5 } & B & 25 & 22.04 & 2.406 \\
\hline \multicolumn{4}{|c|}{ Table 1. Age Distribution } \\
\hline
\end{tabular}

This table shows mean age group in Group A is 21.5 yrs. and Group B is 22 yrs. and the p-value of the table is .592 which is not statistically significant.

\begin{tabular}{|c|c|c|c|c|c|c|}
\hline & \multicolumn{5}{|c|}{ Crosstab } \\
\hline & & \multicolumn{5}{|c|}{ Count } \\
\hline & & \multicolumn{3}{|c|}{$\begin{array}{c}\text { Tocolytic Drugs } \\
\text { Used }\end{array}$} & & \multirow{2}{*}{ Total } \\
\hline & & A & Percentage & B & Percentage & \\
\hline \multirow{4}{*}{ Parity } & 0 & 11 & $44 \%$ & 12 & \begin{tabular}{|l|}
$48 \%$ \\
\end{tabular} & 23 \\
\hline & 1 & 7 & $29 \%$ & 8 & $32 \%$ & 15 \\
\hline & 2 & 5 & $20 \%$ & 4 & $16 \%$ & 9 \\
\hline & 3 & 2 & $8 \%$ & 1 & $4 \%$ & 3 \\
\hline \multicolumn{2}{|c|}{ Total } & 25 & & 25 & & 50 \\
\hline & & ble 2 & arity * Toco & tic D & Igs Used & \\
\hline
\end{tabular}

This table shows both groups are incomparable in respect of parity. Primigravida i.e. more in Group B (48\%) as compared to Group A (44\%) and the p-value is .555 which is not statistically significant

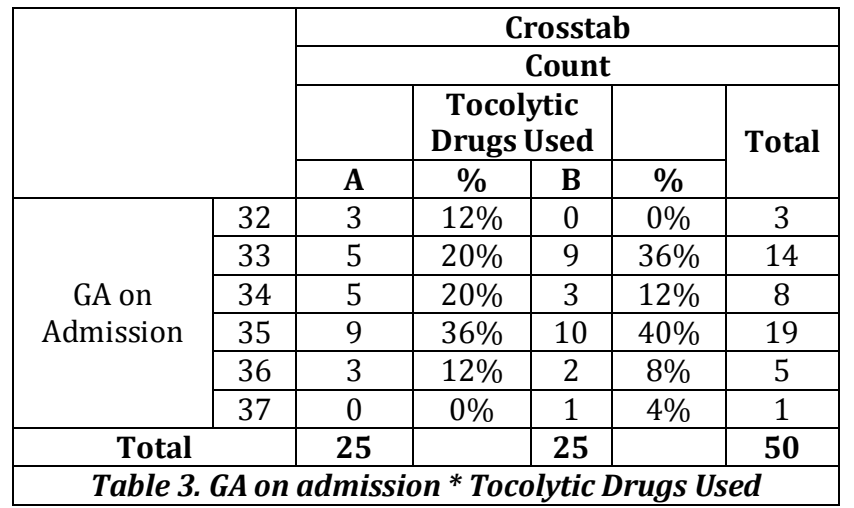

This table shows distribution of pregnant mother according to gestation age in two different groups (Group A Nifedipine and Group B Isoxsuprine) and it is incomparable. Majority of the patients were between 33 - 35 weeks of gestation ( $88 \%$ in Group B vs. $76 \%$ in Group A), and the pvalue is 0.317 which is not statistically significant.

\begin{tabular}{|c|c|c|c|c|c|c|}
\hline & \multirow{2}{*}{\multicolumn{5}{|c|}{$\begin{array}{c}\text { Crosstab } \\
\text { Count }\end{array}$}} \\
\hline & & & & & & \\
\hline & & \multirow[b]{2}{*}{$\mathbf{A}$} & \multicolumn{2}{|c|}{$\begin{array}{c}\text { Tocolytic } \\
\text { Drugs Used }\end{array}$} & \multirow[b]{2}{*}{$\%$} & \multirow[t]{2}{*}{ Total } \\
\hline & & & $\%$ & B & & \\
\hline \multirow{4}{*}{$\begin{array}{c}\mathrm{P} / \mathrm{V} \\
\text { Findings } \\
\text { on } \\
\text { Admissio } \\
\mathrm{n}\end{array}$} & $\begin{array}{c}\text { OS- } \\
\text { Closed }\end{array}$ & 18 & $72 \%$ & 18 & $72 \%$ & 36 \\
\hline & OS $>2 \mathrm{~cm}$ & 5 & $20 \%$ & 0 & $0 \%$ & 5 \\
\hline & $\mathrm{OS}>2 \mathrm{~cm}$ & 0 & $0 \%$ & 4 & $16 \%$ & 4 \\
\hline & PPROM & 2 & $8 \%$ & 3 & $12 \%$ & 5 \\
\hline \multicolumn{2}{|c|}{ Total } & 25 & & 25 & & 50 \\
\hline \multicolumn{7}{|c|}{$\begin{array}{c}\text { Table 4. P/V Findings on admission * Tocolytic Drugs } \\
\text { Used }\end{array}$} \\
\hline
\end{tabular}

This table shows distribution of the patients according to $\mathrm{P} / \mathrm{V}$ findings during admission, which shows that maximum patients got admitted in preterm labour with os-closed condition and the p-value is. 027 which is statistically significant.

\begin{tabular}{|c|c|c|c|c|c|}
\hline \multicolumn{7}{|c|}{ Group Statistics } \\
\hline & $\begin{array}{c}\text { Tocolytic } \\
\text { Drugs } \\
\text { Used }\end{array}$ & $\mathbf{N}$ & Mean & $\begin{array}{c}\text { Std. } \\
\text { Deviation }\end{array}$ & $\begin{array}{c}\text { Std. } \\
\text { Error } \\
\text { Mean }\end{array}$ \\
\hline $\begin{array}{c}\text { Prolongation } \\
\text { of pregnancy }\end{array}$ & $\mathrm{A}$ & 25 & 24.20 & 8.031 & 1.606 \\
\cline { 2 - 6 } Table 5. Prolongation of Pregnancy * Tocolytic Drugs \\
Used
\end{tabular}

This table shows prolongation of pregnancy was more in Group A of 24.2 days when compared to Group B i.e. 14.96 days. The prolongation of pregnancy is statistically significant (p-value of .393), as it is short duration of study and sample size is small where they presented at different gestational age.

\begin{tabular}{|c|c|c|c|c|c|c|}
\hline & \multicolumn{5}{|c|}{ Count } \\
\hline & & \multirow[b]{2}{*}{ A } & \multicolumn{2}{|c|}{$\begin{array}{l}\text { Tocolytic } \\
\text { Drugs Used }\end{array}$} & \multirow[b]{2}{*}{$\%$} & \multirow[t]{2}{*}{ Total } \\
\hline & & & $\%$ & B & & \\
\hline \multirow{8}{*}{$\begin{array}{c}\text { Delivery } \\
\text { Weeks }\end{array}$} & 33 & 1 & $4 \%$ & 0 & $0 \%$ & 1 \\
\hline & 34 & 1 & $4 \%$ & 3 & $12 \%$ & 4 \\
\hline & 35 & 0 & $0 \%$ & 4 & $16 \%$ & 4 \\
\hline & 36 & 6 & $24 \%$ & 5 & $20 \%$ & 11 \\
\hline & 37 & 2 & $8 \%$ & 3 & $12 \%$ & 5 \\
\hline & 38 & 4 & $16 \%$ & 8 & $32 \%$ & 12 \\
\hline & 39 & 8 & $32 \%$ & 2 & $8 \%$ & 10 \\
\hline & 40 & 3 & $12 \%$ & 0 & $0 \%$ & 3 \\
\hline \multicolumn{2}{|c|}{ Total } & 25 & & 25 & & 50 \\
\hline \multicolumn{7}{|c|}{$\begin{array}{c}\text { Table 6. Delivery Weeks * Tocolytic Drugs Used Delivery } \\
\text { Weeks * Tocolytic Drugs Used Cross-Tabulation }\end{array}$} \\
\hline
\end{tabular}

This table shows period of gestation at the time of delivery $\geq 37$ weeks cases in Group A of $68 \%$ in comparison to $52 \%$ in Group B, and the p-value of .047 which is statistically significant, which signify Nifedipine is better choice of tocolytics as compared to Isoxsuprine to arrest preterm labour and more chances towards term delivery. 


\begin{tabular}{|c|c|c|c|c|c|}
\hline \multicolumn{7}{|c|}{ Group Statistics } \\
\hline & $\begin{array}{c}\text { Tocolytic } \\
\text { Drugs } \\
\text { Used }\end{array}$ & N & Mean & $\begin{array}{c}\text { Std. } \\
\text { Deviation }\end{array}$ & $\begin{array}{c}\text { Std. } \\
\text { Error } \\
\text { Mean }\end{array}$ \\
\hline Birth wt. & $\mathrm{A}$ & 25 & 2.36 & .490 & .098 \\
\cline { 2 - 6 } & $\mathrm{B}$ & 25 & 2.28 & .458 & .092 \\
\hline APGAR & $\mathrm{A}$ & 25 & 9.32 & 1.030 & .206 \\
\cline { 2 - 6 } Score & $\mathrm{B}$ & 25 & 7.40 & 1.323 & .265 \\
\hline Table 7. Birth Wt. and APGAR Score at Delivery * Tocolytic \\
Drugs Used \\
\hline
\end{tabular}

This table shows mean birth weight of infants delivered was $2.3 \mathrm{~kg}$ in Group A with Apgar scores of $>9$ at 1 minute of birth and mean birth weight of infants delivered was $2.2 \mathrm{~kg}$ in Group B with Apgar scores of $>7$ at birth, which signify using Nifedipine (Group A) to arrest preterm labour can significantly increase the chances of better foetal outcome. The p-value for the birth weight is .243, which is statistically significant, but the p-value for APGAR score is .656 which is not statistically significant.

\section{DISCUSSION}

Incidence of preterm labour is around $24 \%$ in India. It has been found to be around $18 \%$ in our hospital according to the data analysis of the census of this hospital, which is almost similar to The Lancet, June 2012 report.[3] Patients in both groups were well matched regarding age, antenatal care, parity, previous obstetric history and socio-economic status.

Preterm birth is a leading cause of infant death, which also carries a large economic burden both for the families and the society. It has been suggested that for reducing the preterm birth rates, improved health care for women is required not only during pregnancy and delivery but also before conception. Better understanding of the prepregnancy risk factors for preterm birth is needed, so that women at high risk can be identified and provided targeted services to mitigate their risks. Some risk factors have been identified, particularly low socioeconomic status, short spacing between pregnancies and high and low maternal age. $[2,4,5]$

In our study, the average age group of the patients are around 20 - 21 yrs., which is a major risk factor for developing preterm labour and they also belong to the low socioeconomic status. In preterm labour the moto of the management is to prolong the duration of pregnancy, to achieve a better pregnancy outcome which can be achieved by using some better tocolytic drugs, so that betamethasone for lung maturity can act properly to reduce the chances of RDS.

In our study the mean prolongation of pregnancy in this study was 24 days in Nifedipine group and 15 days in Isoxsuprine group, which is almost similar to those reported by Kalita $D$ et al (31 days in Nifedipine Group and 23 days in Isoxsuprine Group).[6,7,8]

Period of gestation at the time of delivery $\geq 37$ weeks was $68 \%$ in Group A compared to 52\% in Group B. Mean birth weight of infants delivered was $2.3 \mathrm{~kg}$ in Group A with Apgar scores of $>9$ at birth and Mean birth weight of infants delivered was $2.2 \mathrm{~kg}$ in Group B with Apgar scores of $>7$ at birth, which signify successfulness of Nifedipine to arrest preterm labour is much more than Isoxsuprine in respect of term delivery and better foetal outcome, which is almost similar to those reported by Kedar et al (88\% Nifedipine group and $76 \%$ in Isoxsuprine group) ${ }^{[7]}$ and according to RCOG recommendations. [9]

\section{Limitation}

Due to the short duration of study, the sample size taken was less.

\section{CONCLUSION}

Use of tocolytic drug is associated with a prolongation of pregnancy for upto 7 days, but with no significant effect on preterm birth and no clear effect on perinatal or neonatal morbidity. However, tocolysis should be considered if the few days gained would be put to good use, such as completing a course of corticosteroids or in utero transfer. However, this benefit has not been formally evaluated in randomised trials. If reliable prediction as to which women in suspected preterm labour are likely to have a preterm birth was possible, the use of tocolysis could be reserved for those women. There is limited evidence that use of nifedipine, rather than a beta-agonist (Isoxsuprine), is associated with improved short-term neonatal outcome, because Nifedipine is a well-tolerated, very effective and very safe tocolytic agent when seen with respect to Isoxsuprine with less maternal complications in management of preterm labour.

\section{REFERENCES}

[1] Begum F, Buckshe K, Pande JN. Risk factors associated with preterm labor. Bangladesh Med Res Counc Bull 2003;29(2):59-66.

[2] Behrman RE, Butler SA. Preterm birth: causes, consequences and prevention. Washington, DC: The National Academies Press 2007.

[3] Blencowe $\mathrm{H}$, Cousens S, Oestergaard MZ, et al. National, regional and worldwide estimates of preterm birth rates in the year 2010 with time trends since 1990 for selected countries: a systematic analysis and implications. The Lancet 2012;379(9832):2162-72.

[4] Callaghan WM, MacDorman MF, Rasmussen SA, et al. The contribution of preterm birth to infant mortality rates in the United States. Pediatrics 2006;118(4):1566-73.

[5] Goldenberg RL, Culhane JF, Iams JD, et al. Epidemiology and causes of preterm birth. Lancet 2008;371(9606):75-84.

[6] Kalita D, Goswami A, Muzumatar KL. A comparative study of Nifedipine and Isoxsuprine hydrochloride in the management of the pre-term labour. J Obstet Gynecol India 1998;48:47-50.

[7] Gania KM, Shroff SA, Desai S, et al. A prospective comparative study of Nifedipine and Isxosuprine for tocolysis. Bombay Hospital Journal 1999: p. 259.

[8] King JF, Flenady VJ, Papatsonis DNM, et al. Calcium channel blockers for inhibiting preterm labor (Cochrane review). In: The Cochrane Library. Chichester, UK: John Wiley \& Sons, Ltd., 2004:(3).

[9] RCOG. Tocolytic drugs for women in preterm labor. In: Clinical guideline no. I (B). London: RCOG Press 2002. 